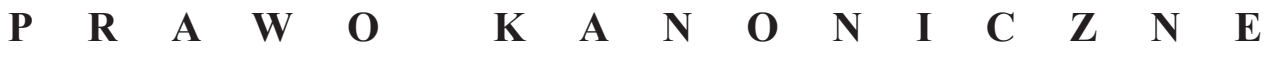

ROCZNIKI NAUK PRAWNYCH

Tom XXIX, numer $3-2019$

DOI: http://dx.doi.org/10.18290/rnp.2019.29.3-10

MIECZYSŁAW RÓŻAŃSKI

\section{ARCHIWUM KAPITUŁY KATEDRALNEJ I KOLEGIACKIEJ}

Kapituły kanoników należą do jednych z starszych instytucji kościelnych działających na przestrzeni wieków1. Mogą one być dwojakiego rodzaju: katedralna (capitulum canonicorum cathedrale) i kolegiacka (capitulum canonicorum

Ks. dr hab. MieCZYSŁAw RóŻAŃSKI, prof. UWM w Olsztynie - kierownik Katedry Historii i Ustroju Państwa i Prawa, Wydział Prawa i Administracji, Uniwersytet Warmińsko-Mazurski w Olsztynie, ul. Warszawska 98, 10-702 Olsztyn; e-mail: mieczyslaw.rozanski@uwm.edu.pl; https:// orcid.org/0000-0003-3345-1740

${ }^{1} \mathrm{~W}$ polskiej historiografii opracowano dzieje wielu kapituł wśród nich należy wskazać wymienić publikacje książkowe: A. KopıczKo, Dzieje Warmińskiej Kapituły Katedralnej, t. II: od 1821 roku, Olsztyn: Instytut Historii i Stosunków Międzynarodowych UWM 2010; Warmińska Kapituła Katedralna. Dzieje i wybitni przedstawiciele, red. A. Kopiczko, J. Jezierski, Z. Żywica, Olsztyn: Instytut Historii i Stosunków Międzynarodowych UWM 2010; W. GóRALSKI, Kapituła katedralna w Płocku XII-XVI w. Studium z dziejów organizacji prawnej kapituł polskich, Płock: Płockie Wydawnictwo Diecezjalne 1979; M. BILSKa-CIEĆWIERZ, Powstanie $i$ organizacja kapitut kolegiackich metropolii gnieźnieńskiej w średniowieczu, Kraków: Societas Vistulana 2007; S. CHоміAK, Świdnicka Kapituła Katedralna, Świdnica: Świdnicka Kuria Biskupia 2009; M. CzYŻAK, Kapituła katedralna w Gnieźnie w świetle metryki z lat 1408-1448, Poznań: UAM. WT. Redakcja Wydawnictw 2003; P. DemBIŃSKI, Poznańska kapituła katedralna schyłku wieków średnich: studium prozopograficzne, Poznań: Wydawnictwo Poznańskiego Towarzystwa Przyjaciół Nauk 2012; S. GRAD, M. RóżAŃski, Kapituła Katedralna Łódzka, Łódź: Archidiecezjalne Wydawnictwo Łódzkie 2007; K. DolA, Wrocławska kapituła katedralna w XV w., Nysa [b.w.] 1977; H. GerLIC; Kapituła głogowska w dobie piastowskiej i jagiellońskiej (1120-1526), Gliwice: Wydawnictwo NOTA 1993; J. KoRYTKOwsKI, Prałaci i kanonicy katedry metropolitalnej gnieźnieńskiej od roku 1000 do dni naszych, t. I-IV, Gniezno: [b.w.] 1883; L. KRóLIK, Kapituła kolegiacka w Warszawie do końca XVIII wieku, Warszawa: Wydawnictwo Archidiecezji Warszawskiej 1990; S. LiBRowsKI, Kapituła katedralna włocławska - zarys dziejów i organizacji, Włocławek [b.w.] 1948; A. RADZIMIŃsKI, Duchowieństwo kapitulne w Polsce średniowiecznej i wczesnonowożytnej - pochodzenie i funkcjonowanie elity kościelnej, Toruń: Wydawnictwo Uniwersytetu Mikołaja Kopernika 2000; W. BochniaK, Kapituła katedralna w Legnicy, Legnica: Parafia Katedralna p.w. św. Piotra i Pawła 2000; J. SzYmaŃski, Kapituła kolegiacka w Wojniczu (1465-1786), Lublin: Towarzystwo Naukowe KUL 1962. Znacznie obszerniejsza bibliografia w: H.E. WycZawski, Przygotowanie do studiów w archiwach kościelnych, red. T. Moskal, A.K. Sitnik, Kalwaria Zebrzydowska: Wydawnictwo OO. Bernardynów „Calvarianum” 2013. 
collegiale). Pierwsza z nich funkcjonuje przy kościele katedralnym, a druga przy innym znaczniejszym kościele w diecezji. Kapituła katedralna różni się kapituły kolegiackiej tym, że oprócz funkcji liturgicznych, ma do spełnienia zadania określone przez prawo oraz zlecone przez biskupa diecezjalnego. Zawsze też kapituły prowadziły archiwa, w których przechowywano otrzymane lub wytworzone przez nią akta i dokumenty. Celem artykułu jest przedstawienie jakie są współczesne przepisy prawne dotyczące funkcjonowania archiwów tych dwóch instytucji kościelnych w świetle ustawodawstwa synodalnego polskiego po promulgacji Kodeksu Prawa Kanonicznego z 1983 r.

\section{KAPITUŁY KATEDRALNE I KOLEGIACKIE}

Początek istnienia kapituł związany jest dwoma czynnikami. Pierwszym jest uczestnictwo grupy duchownych. którzy pomagali biskupowi w kierowaniu diecezją, wspierając go radą i pomocą, a drugim było ich życie wspólne w mieście biskupim. Inicjatywa ta zaczęła się od IV w. Duchowni ci zaczęli prowadzić życie wspólne w domu biskupim i zachowywali określoną regułę. Tę formę życia nazywano życiem kanonicznym. Tych zaś, którzy je prowadzili zwano kanonikami. Nazwę kanonicy jedni wywodzą z faktu, że duchowni ci byli zapisani w kanonie, czyli na liście duchownych, inni że żyli według kanonów prawa kościelnego, innego niż reguła zakonna, a jeszcze inni, że odmawiali pacierze kanoniczne. Twórcą życia wspólnotowego duchownych był Biskup Euzebiusz (†371), a propagatorem takiego życia był św. Augustyn. Regułę wspólnego życia ułożył biskup Metzu św. Chrodegang (742-766) a przerobił ją diakon z tego samego miasta Amalarius. Synod Akwizgrański z 816 r. (Institutio Aquisgranensis), potwierdził ją i polecił wprowadzać w życie ${ }^{2}$. Według niej duchowni mieszkali przy kościele katedralnym tworząc jakby klasztor i wspólnie rozważali Pismo św. ${ }^{3} \mathrm{~W}$ X w. nastąpił upadek życia wspólnego prezbiterów, a w wieku następnym podjęto próbę przywrócenia tej formy życia wspólnego ze ślubami i zachowaniem reguły, co dało początek wspólnoty tzw. canonici regulares. Zwiększenie znaczenia kapituł nastąpiło w XII w., kiedy otrzymały osobowość prawną i przyznano im prawo wyboru biskupów ${ }^{4}$.

\footnotetext{
2 E. Rittner, Prawo kościelne katolickie, t. I, Kraków [b.w.] 1899, s. 190-194.

${ }^{3}$ G.P. Marchal, Domkapitel, w: Theologische Realenzyklopädie, t. IX, Berlin-New York: De Gruyter 1982, s. 136; K. Nitzschke, Domkapitel, w: Evangekisches Kirchenlexikon, t. I, Gottingen: V \& R 1956, kol. 964; J. BorUCKI, Kapituła katedralna i Rada Kapłańska - stary i nowy senat biskupa diecezjalnego, „Studia Włocławskie” 9 (2006), s. 224.

${ }^{4}$ X A.S., Kapituła, w: Encyklopedia Kościelna, t. IX, Warszawa [b.w.] 1876, s. 519-520.
} 
W początkach XIII w. sfinalizowany został proces rozwoju praw kapitulnych zmierzający przede wszystkim do większego wyemancypowania się tego kolegium spod władzy biskupa. Na synodzie rzymskim papieża Mikołaja II w 1059 r., kapituły otrzymały osobowość prawną, a konkordat wormacki (1122 r.) przyznał kapitułom prawo wyboru biskupa. Te prawa potwierdził Sobór Laterański II w 1139 r. $^{5}$ Kapituła nabrała wówczas cech korporacji samoistnej, posiadającej własny samorząd ${ }^{6}$. Wówczas uzyskała tzw. prawo konsensu, które wyrażało się w konieczności uzyskiwania przez biskupa rady lub zgody kolegium kanonickiego - jako osoby prawnej - na podjęcie ważniejszych czynności jurysdykcyjnych w diecezji ${ }^{7}$. Szczególnie ważną rolę kapituła katedralna odgrywała w diecezji w razie niemożności sprawowania rządów przez biskupa (sede impedita) oraz podczas wakatu stolicy biskupiej (sede vacante) ${ }^{8}$.

Sobór Trydencki (1545-1563) ograniczył rolę kapituł katedralnych i podporządkował je biskupom diecezjalnym. Przyznał biskupom prawo wizytowania kapituł katedralnych oraz wprowadzania w nich zmian, wymagał, aby wszyscy kanonicy posiadali święcenia wyższe i aby przynajmniej połowa kanoników kapituły miała święcenia prezbiteratu. Zakazał powiększać jej skład bez uzyskania uprzedniej zgody papieża. Określił także wiek otrzymania godności w kapitule. Prałatem nie mogła zostać osoba przed rozpoczęciem 24 roku życia, a kanonikiem przed rozpoczęciem 22 lat. Wszyscy prałaci w kapitule (dignitataes) i przynajmniej połowa kanoników mających tytuł insignes powinni być magistrami lub doktorami teologii lub prawa kanonicznego. Ponadto szczegółowo określono obowiązki członków kapitul'

Kodeksu Prawa Kanonicznego z 1917 r. ${ }^{10}$ poświęcił kapitułom 32 kanony. Kapituła katedralna stanowiła senat i radę biskupa. Jej zadaniem było wspieranie go radami w rządzeniu diecezją oraz zastępowanie biskupa w rządzeniu diecezją w czasie wakansu stolicy biskupiej. Oprócz tego jej zadaniem jej była troska

${ }^{5}$ Sobór Laterański II, Kanon XXVIII, w: Dokumenty soborów powszechnych. Tekst grecki, łaciński, polski, t. II, oprac. A. Baron H. Pietras, Kraków: Wydawnictwo WAM 2007, s. 161.

${ }^{6}$ J. Wroceński, Rola $i$ zadania prezbiterium $w$ życiu Kościoła partykularnego, Warszawa: Wydawnictwo ATK 1998, s. 68-69; S. ZACHOROwsKI, Rozwój i ustrój kapitul polskich w wiekach średnich, Kraków [b.w.] 1912, s. 57-58, 79; T. SiLnicki, Dzieje i ustrój Kościoła Katolickiego na Ślasku do końca XIV w., Warszawa: Wydawnictwo PAX 1953, s. 341-342.; GóRALSKI, Kapituła, s. 58.

${ }^{7}$ W. Abraham, Organizacya Kościoła w Polsce do połowy XII w., Lwów [b.w.] 1893, s. 184; Góralski, Kapituła, s. 59; Zachorowski, Rozwój, s. 69; Silnicki, Dzieje, s. 84-85; S. LiBrowski, Kapituła katedralna włocławska, s. 21.

${ }^{8}$ Grad, RóżAŃSKI, Kapituła Katedralna, s. 121.

${ }^{9}$ Concilum Trididentinum, Sessio XXIV, c. 12 de reformatione.

${ }^{10}$ Codex Iuris Canonici Pii X Pontificis Maximi iussu digestus Benedicti Papae XV auctoritate promulgatus (27.05.1917), AAS 9 (1917), pars II, s. 1-593 [dalej cyt.: CIC]. 
o uroczysty kult liturgiczny w kościele katedralnym ${ }^{11}$. Kodeks szczegółowo wyliczał wypadki, kiedy biskup diecezjalny miał obowiązek zasięgnąć opinii kapituły katedralnej. Było to w następujących przypadkach:

- ustanawianie egzaminatorów prosynodalnych i proboszczów konsultorów (kan. 386 CIC);

- usuwanie egzaminatorów i proboszczów konsultorów (kan. 388 CIC);

- określanie prebend w kapitule (kan. 394 § 1 i 3 CIC);

- ustalanie terminów działania kanonika teologa (kan. 400 § 1 CIC);

- rezerwowanie grzechów poza synodem (kan. 895 CIC);

- określanie taksy diecezjalnej (kan. 1234 § 1 CIC);

- organizowanie nadzwyczajnych procesji (kan. 1292 CIC);

- ustanawianie coetus deputatorum dla seminarium (kan. 1359 § 2 CIC);

- zmiany w beneficjach (kan. $1428 \S 2$ CIC);

- mianowanie diecezjalnej rady administracyjnej (kan. 1520 § 1 CIC);

- karne zniesienie lub przeniesienie siedziby parafii (kan. 2292 CIC);

- nadawanie beneficjów w kapitule (kan. 403 CIC);

- zamiana parafii usuwalnych na nieusuwalne (kan. 454 § 3 CIC).

Przewidywał również sytuacje, w których biskup potrzebował zgody kapituły katedralnej:

- na erygowanie bractw lub pobożnych stowarzyszeń w kościele katedralnym (kan. 712 § 2 CIC);

- na alienację majątku kościelnego (kan. 1532 § 3 CIC).

Podczas prac Soboru Watykańskiego II zgłaszano wiele uwag dotyczących funkcjonowania tej instytucji oraz wskazywano na potrzebę jej reformy ${ }^{12}$. Potwierdził to soborowy dekret Christus Dominus ${ }^{13}$, wskazując, że kapituła, o ile istnieje taka potrzeba, powinna zostać zreorganizowana ( $\mathrm{nr} 27)$. W okresie posoborowym nowe zadania i rolę kapituły wyznaczały akty normatywne: motu proprio papieża Pawła VI Ecclesiae Sanctae ${ }^{14}$; list okólny Kongregacji ds. Duchowieństwa Presbyteri

${ }^{11}$ J. Dyduch, Kapitula Katedralna i Rada Kapłańska, „Prawo Kanoniczne” 25 (1982), nr 3-4, s. $79-81$.

${ }^{12} \mathrm{~K}$. Wętкowski, Kapituła katedralna w świetle postanowień Soboru Watykańskiego II i norm Kodeksu prawa kanonicznego z 1983 roku, „Prawo i Kościół” 2 (2000), s. 78-79.

${ }^{13}$ Sacrosanctum Concilium Oecumenicum Vaticanum II, Decretum de pastorali episcoporum munere in Ecclesia Christus Dominus (28.10.1965), AAS 58 (1966), s. 673-696; tekst polski: SoBóR WaTYKAŃSKi II, Konstytucje, dekrety, deklaracje, tekst polski, nowe thumaczenie, Pallottinum, Poznań 2002, s. 236-258.

${ }^{14}$ Paulus PP. VI, Litterae Apostolicae Motu Proprio Datae Ecclesiae Sanctae Normae ad quaedam exsequenda SS. Concilii Vaticani II Decreta statuuntur, AAS 58 (1966) s. 757-787. 
sacra (11 kwietnia 1970 r.) ${ }^{15}$; przepisy Rady ds. Publicznych Kościoła w sprawie wyboru biskupów w Kościele łacińskim (25 marca 1972 r. $)^{16}$; instrukcja Kongregacji Biskupów Ecclesiae Imago (22 lutego 1973 r.) ${ }^{17}$. Wyznaczają one doradczą rolę kapituły katedralnej, pozostawiając jej tylko część uprawnień zawartych w Kodeksie z 1917 r.

Istotne zmiany w funkcjonowaniu kapituł przyniósł Kodeks Prawa Kanonicznego z 1983 r. ${ }^{18}$ Według niego kapituła katedralna i kolegiacka to kolegium kapłanów, którego zadaniem jest sprawowanie bardziej uroczystych czynności liturgicznych w kościele katedralnym lub kolegiackim. Kapituła katedralna ma ponadto do spełnienia zadania określone przez prawo lub zlecone jej przez biskupa diecezjalnego (kan. 503 KPK/83).

Prawo zleca kapitule katedralnej niewiele zadań. Wszyscy kanonicy katedralni mają uczestniczyć w synodzie diecezjalnym (kan. $463 \S 1,3^{\circ} \mathrm{KPK} / 83$ ), natomiast w synodzie prowincjalnym bierze udział jej dwóch przedstawicieli, którzy zostali wybrani kolegialnie. Posiadają oni głos doradczy (kan. $443 \S 5 \mathrm{KPK} / 83$ ). Legat papieski ma obowiązek zwrócenia się m.in. do niektórych członków kapituły katedralnej po opinię dotyczącą kandydatów na biskupa diecezjalnego lub koadiutora (kan. 377 § $3 \mathrm{KPK} / 83$ ).

\section{ARCHIWA KAPITUŁ KATEDRALNYCH I KOLEGIACKICH}

Kapituły od początku swojego działania gromadziły rękopisy i dyplomy pergaminowe. Szczególną opieką otaczały dokumenty dotyczące wszelkiego rodzaju nadań, stosunków majątkowych, instytucji będących pod ich opieką. Wraz z dalszą działalnością do zasobu archiwum kapitulnego dochodziły księgi i akta lub dokumenty związane z funkcjonowaniem kapituły np. metryki kapitulne, księgi obowiązków mszalnych i chórowych, księgi testamentów, rachunki prokuratorskie, inwentarze, księgi instalacji, księgi wizytacji ${ }^{19}$. Materiały te były przechowywane

\footnotetext{
15 Sacra Congregatio pro Clericis, Litterae Circulares ad Praesides Conferentiarum Episcopalium de Consiliis Presbyteralibus iuxta placita Congregationis Plenariae die 10 Octobris 1969 habitae, AAS 62 (1970), s. 459-465.

${ }^{16}$ Acta Consilit pro Publicis Ecclesiae Negotiss, De promovendis ad Episcopatum in Ecclesia latina, AAS 64 (1972), s. 386-391.

${ }^{17}$ Kongregacja DS. Biskupów, Directorium Ecclesiae imago de pastorali ministerio Episcoporum, [w:] Enchiridion Vaticanum, t. IV, Roma [b.w.] 1978.

${ }^{18}$ Codex Iuris Canonici auctoritate Ioannis Pauli PP. II promulgatus (25.01.1983), AAS 75 (1983), pars II, s. 1-317; tekst polski: Kodeks Prawa Kanonicznego, przekład polski zatwierdzony przez Konferencję Episkopatu, Poznań: Pallotinum 1984 [dalej cyt.: KPK/83].

${ }^{19}$ GóralsKi, Kapituła, s. 232.
} 
w pomieszczeniach kapitulnych i pilnie strzeżone. Normy prawne dotyczące ich bezpieczeństwa znajdowały się w statutach i podejmowane były podczas posiedzeń kapitulnych. Współczesne przepisy dotyczące funkcjonowania archiwum znajdują się w statutach poszczególnych kapituł.

Do akt synodalnych Kościoła w Polsce dołączone zostały statuty następujących kapituł katedralnych i kolegiackich znajdujących się w (archi)diecezjach:

- białostockiej - Statut Białostockiej Kapituły Metropolitalna, Statut Kapituły Kolegiackiej Krypiańskieje;

- drohiczyńskiej - Statut Drohiczyńskiej Kapituły Katedralnej, Statut Kolegiackiej Kapituły Węgrowskiej ${ }^{21}$;

- ełckiej - Statut Ełckiej Kapituły Katedralnej22;

- łódzkiej - Statut Kapituły Archikatedralnej Łódzkiej ${ }^{23}$;

- pelplińskiej - Statuty Kapituły Kolegiackiej Kartuskiej, Statuty Kapituły Kolegiackiej Koronowskiej ${ }^{24}$;

- płockiej - Statut Kapituły Katedralnej Płockiej, Statut Kapituły Kolegiackiej Pułtuskiej, Statut Kapituły Kolegiackiej Świętego Michała w Płocku²,

- poznańskiej - Statuty Kapituły Metropolitalnej w Poznaniur ${ }^{26}$;

- przemyskiej - Statuty Przemyskiej Kapituły Metropolitalnej obrządku Łacińskiego, Statuty Brzozowskiej Kapituły Kolegiackiej²7

- rzeszowskiej - Statut Kapituły Katedralnej w Rzeszowie, Statut Kapituły Bieckiej $^{28}$;

${ }^{20}$ I Synod Archidiecezji Białostockiej, Białystok: Kuria Metropolitalna Białostocka 2000 [dalej cyt: ISynBiał].

${ }^{21}$ I Synod Diecezji Drohiczyńskiej. Statuty. Dokumenty wykonawcze, Drohiczyn: Drohiczyńskie Wydawnictwo Diecezjalne 1997 [dalej cyt.: ISynDroh].

${ }^{22}$ I Synod Diecezji Ełckiej 1997-1999, Ełk: Kuria Biskupia Diecezji Ełckiej 1999 [dalej cyt.: ISynEŁ].

${ }^{23}$ III Synod Archidiecezji Łódzkiej (1996-1998), Łódź: Wydawnictwo Archidiecezjalne Łódzkie 1999 [dalej cyt.: IIISynLd].

${ }^{24}$ Statuty I Synodu Diecezji Pelplińskiej, Pelplin: Bernardinum 2001 [dalej cyt.: ISynPel].

${ }^{25}$ Gdzie jest Bóg tam jest przyszłość. XLIII Synod Diecezji Płockiej. Prawo partykularne i program odnowy pastoralnej Kościoła Płockiego, Płock: Płocki Instytut Wydawniczy 2015 [dalej cyt.: 43SynPło].

${ }^{26}$ Synod Archidiecezji Poznańskiej 2004-2008. Zwołany i przeprowadzony przez Arcybiskupa Stanisława Gądeckiego, t. I: Dokumenty, Poznań: Wydawnictwo Świętego Wojciecha 2008 [dalej cyt.: SynPozn].

${ }^{27}$ Synod Archidiecezji Przemyskiej 1995-2000. Statuty i aneksy, Przemyśl: Wydawnictwo Archidiecezji Przemyskiej 2000 [dalej cyt.: SynPrze].

${ }^{28}$ Pierwszy Synod Diecezji Rzeszowskiej 2001-2004, Rzeszów: Poligrafia Wyższego Seminarium Duchownego 2004 [dalej cyt.: ISynRze]. 
- sandomierskiej - Statut Sandomierskiej Kapituły Katedralnej, Statut Konkatedralnej Kapituły Kolegiackiej w Stalowej Woli, Statuty Kapituły Kolegiackiej w Opatowie ${ }^{29}$;

- sosnowieckiej - Statut Sosnowieckiej Kapituły Katedralnej, Statuty Kapituły Kolegiackiej Opolsko-Pilickiej, Statuty Kapituły Kolegiackiej Św. Wojciecha w Jaworznie ${ }^{30}$;

- toruńskiej - Statuty Kapituły Katedralnej Toruńskiej, Statuty Kapituły Konkatedralnej Chełmżyńskiej, Statuty Kapituły Kolegiackiej Grudziądzkiej ${ }^{31}$;

- warmińskiej - Statut Warmińskiej Kapituły Katedralnej we Fromborku, Statut Kapituły Kolegiaty Najświętszego Zbawiciela w Dobrym Mieście, Statut Kapituły Kolegiackiej przy kościele Świętych Apostołów Piotra i Pawła w Lidzbarku Warmińskim, Statut Kapituły Kolegiackiej w Kętrzynie ${ }^{32}$;

- warszawskiej - Statut Kapituły Metropolitalnej Warszawskiej, Statuty Kapituły Świętej Opatrzności Bożej przy kolegiacie św. Anny w Wilanowie ${ }^{33}$;

- warszawsko-praskiej - Statut Kapituły Katedralnej Warszawsko-Praskiej, Statut Kapituły Kolegiackiej Radzymińskiej ${ }^{34}$.

W każdym ze statutów znajduje się obowiązek prowadzenie archiwum kapituły. Zadanie to zapisane zostało albo w formie ogólnej, albo poprzez wskazanie kanonika, który ma sprawować nad nim nadzór. W sposób ogólny zapisano przy użyciu sformułowania ,akta kapituły są przechowywane w archiwum kościoła kolegiackiego” (Statut Kapituły Bieckiej - § 14; Statuty Kapituły Kolegiackiej Koronowskiej - § 15; Statuty Kapituły Kolegiackiej Kartuskiej - §15) - wówczas brak jest wskazania osoby, która jest odpowiedzialna za opiekę nad materiałami archiwalnymi. Podobny sens zawiera art. 14 Statutu Sosnowieckiej Kapituły Katedralnej, który wskazuje gdzie, czyli w jakim miejscu, znajduje się archiwum Kapituły, a nie określa, kto ma być spośród kanoników Kapituły odpowiedzialny za przekazanie do kurii lub archiwum diecezjalnego materiałów archiwalnych wytworzonych przez Kapitułę ${ }^{35}$.

${ }^{29}$ Aby byli jedno. Drugi Synod Diecezji Sandomierskiej. Dekrety i instrukcje, Sandomierz: Wydawnictwo Diecezjalne 1999 [dalej cyt.: IISynSan].

${ }^{30}$ I Synod Diecezji Sosnowieckiej. Prawo Partykularne Kościoła Sosnowieckiego, Sosnowiec: Wydawnictwo Diecezjalne 2005 [dalej cyt.: ISynSosn].

${ }^{31}$ Pierwszy Synod Diecezji Toruńskiej. Prawo partykularne Kościoła Toruńskiego, Toruń: Toruńskie Wydawnictwo Diecezjalne 2011 [dalej cyt.: ISynTor].

${ }^{32}$ I (XIV) Synod Archidiecezji Warmińskiej (2006-2012). Misja Kościoła Warmińskiego w dziele Nowej Ewangelizacji, Olsztyn: Wydział Duszpasterski Kurii Archidiecezji Warmińskiej 2012 [dalej cyt.: ISynWarm].

${ }^{33}$ IV Synod Archidiecezji Warszawskiej, Warszawa: Wydawnictwo AW 2003 [dalej cyt.: 4SynWar].

${ }^{34}$ Pierwszy Synod Diecezji Warszawsko-Praskiej, Warszawa: Wydawnictwo Diecezji Warszawsko-Praskiej 2000 [dalej cyt.: ISynWar-Pr].

${ }^{35}$ ISynSosn, s. 145. 
W większości statuty określają stanowisko kanonika odpowiedzialnego za prowadzenie archiwum. Są to:

- bibliotekarz i archiwista - Kapituła Metropolitalna w Przemyślu ${ }^{36}$; Kapituła Kolegiacka Brzozowska ${ }^{37}$;

- prepozyt - Kapituła Kolegiacka w Dobrym Mieście ${ }^{38}$; Kapituła Kolegiacka Opatrzności Bożej w Wilanowie ${ }^{39}$;

- kanclerz - Kapituła Metropolitalna w Warszawie ${ }^{40}$;

- sekretarz - Białostocka Kapituła Metropolitalna ${ }^{41}$; Kapituła Metropolitalna w Poznaniu ${ }^{42}$; Kapituła Kolegiacka w Radzyminie ${ }^{43}$; Kapituła Katedralna Warszawsko-Praska ${ }^{44}$; Kapituła Kolegiacka w Kętrzynie ${ }^{45}$; Kapituła Katedralna we Fromborku ${ }^{46}$; Kapituła Kolegiacka w Lidzbarku Warmińskim ${ }^{47} 1$ Kapituła Katedralna w Toruniu ${ }^{48}$; Kapituła Konkatedralna w Chełmży ${ }^{49}$; Kapituła Kolegiacka w Grudziądzu ${ }^{50}$; Kapituła Kolegiacka Okulsko-Pilicka ${ }^{51}$; Kapituła Kolegiacka Świętego Wojciecha w Jaworznie ${ }^{52}$; Kapituła Katedralna w Drohiczynie $^{53}$; Kapituła Kolegiacka Węgrowska ${ }^{54}$; Kapituła Katedralna w Ełku ${ }^{55}$; Kapituła Kolegiacka w Pułtusku ${ }^{56}$.

- kustosz - Kapituła Katedralna w Sandomierzu ${ }^{57}$; Konkatedralna Kapituła Kolegiacka w Stalowej Woli ${ }^{58}$; Kapituła Kolegiacka w Opatowie ${ }^{59}$; Kapituła

${ }^{36}$ SynPrze, s. 184.

${ }^{37}$ Tamże, s. 194.

${ }^{38}$ ISynWarm, s. 281.

39 4SynWar, s. 178.

40 Tamże, s. 172.

${ }^{41}$ ISynBiał, s. 229; do obowiązków sekretarza należy przekazywanie do archiwum kapitulnego, po upływie pięciu lat, nagromadzonych pism urzędowych.

${ }^{42}$ SynPozn, s. 451.

${ }^{43}$ ISynWar-Pr, s. 169.

${ }^{44}$ Tamże, s. 161.

${ }^{45}$ ISynWarm, s. 293.

46 Tamże, s. 347.

${ }^{47}$ Tamże, s. 362.

48 ISynTor, s. 183 .

49 Tamże, s. 191.

${ }^{50}$ Tamże, s. 198.

${ }^{51}$ ISynSosn, s. 149.

52 Tamże, s. 155.

${ }^{53}$ ISynDroh, s. 239.

${ }^{54}$ Tamże, s. 251.

${ }^{55}$ I SynEŁ.

56 43SynPło, s. 404.

${ }^{57}$ IISynSan, s. 359.

58 Tamże, s. 366.

${ }^{59}$ Tamże, s. 374. 
Archikatedralna Łódzka ${ }^{60}$; Kapituła Katedralna Płocka ${ }^{61}$; Kapituła Kolegiacka Świętego Michała w Płocku;

- prokurator - Kapituła Metropolitalna w Białymstoku ${ }^{62}$;

- scholastyk - Kapituła Kolegiacka Krypiańska ${ }^{63}$; Kapituła Katedralna w Rzeszowie $^{64}$.

Zadania tych kanoników wobec wytworzonych przez kapitułę materiałów archiwalnych wskazane zostały w sposób dość ogólny. Mają oni: prowadzić archiwum, przechowywać akta archiwum, poprowadzić archiwum, troszczyć się o archiwum. Wszystkie te określenia w swoim zakresie zawierają te czynności, które potrzebne są do funkcjonowania archiwum bieżącego i historycznego. W dalszych częściach statutów wskazane zostało miejsce, gdzie należy przechowywać materiały archiwalne wytworzone przez kapitułę. $Z$ analizy statutów wynika, że co do zasady większość kapituł katedralnych przekazuje materiały archiwalne przez nie wytworzone albo do archiwum bieżącego kurii, albo do archiwum historycznego, czyli archiwum diecezjalnego. W Statucie Kapituły Katedralnej w Ełku wskazano, że mieści się ono w archiwum kurii, a gdy zachodzi potrzeba wyglądu do akt sekretarz powiadamia o tym kanclerza kurii (§ 4). W statucie Kapituły Katedralnej Toruńskiej sekretarz ma troszczyć się o akta, które nie zostały jeszcze przekazane do archiwum diecezjalnego, czyli archiwum historycznego (pkt 17, $2^{\circ}$ ). W Statucie Kapituły Konkatedralnej Chełmżyńskiej i Kapituły Kolegiackiej Grudziądzkiej wskazane zostało, że sekretarze mają troszczyć się o te akta, które nie zostały przekazane do Archiwum Akt Dawnych Diecezji Toruńskiej, czyli do archiwum historycznego (pkt 17, 2 ${ }^{\circ}$ ). Podobnie wskazano w Statucie Kapituły Katedralnej Warszawsko-Praskiej, gdzie materiały archiwalne sekretarz ma przekazać do archiwum diecezjalnego, jakim jest archiwum historyczne. Z tego zadania wynikają wprost obowiązki dyrektora archiwum diecezjalnego, który zobowiązany jest na każde żądanie Kapituły udzielić odpowiednich informacji o stanie zbiorów kapituły (pkt 27).

Inaczej zaznaczono w Statucie Kapituły Metropolitalnej Przemyskiej, która prowadzi własną bibliotekę i archiwum Kapituły, która mieści się w budynku przy ulicy Kapitulnej 2 w Przemyślu (art. 4). Warto wspomnieć, że jest to jedyne takie wskazanie w załączonych do uchwał synodalnych statutach kapitulnych.

Najbardziej szczegółowe informacje dotyczące zasad funkcjonowania archiwum kapituły katedralnej zawarte są w Statucie Warmińskiej Kapituły Katedralnej

\footnotetext{
${ }^{60}$ IIISynŁd, s. 155.

61 43SynPło, s. 696.

${ }^{62}$ ISynBiał, s. 229; do obowiązków prokuratora należy strzeżenie archiwum i biblioteki kapitulnej.

${ }^{63}$ Tamże, s. 239.

${ }^{64}$ ISynRze, s. 275.
} 
we Fromborku. Stanowią one, że Kapituła współpracuje z wieloma instytucjami kościelnymi, samorządowymi, oświatowymi, kulturalnymi, tak krajowymi jak i zagranicznymi w zakresie realizacji swoich celów statutowych, a wśród tych instytucji wymienione są także archiwa (art. 11). Sekretarz Kapituły strzeże archiwum, czyli dokumentów, które nie zostały jeszcze przekazane do Archiwum Archidiecezji Warmińskiej w Olsztynie (art. 23). Archiwum Kapituły mieści się w Archiwum Archidiecezji Warmińskiej w Olsztynie i pozostaje pod bezpośrednim zarządem jego dyrektora (art. 24). Takie rozwiązanie określa, że wytworzone w toku prac Kapituły dokumenty zostają przekazywane przez sekretarza do Archiwum Archidiecezji Warmińskiej, a on sam czuwa nad tymi materiałami, które nie zostały jeszcze włączone do zespołu akt kapitulnych znajdujących się w archiwum. W przepisach nie zostało określone, po jakim czasie sekretarz powinien przekazać materiały do archiwum, czy jest to okres krótki sięgający kilku miesięcy lub roku, czy też jest to okres dłuższy obejmujący kilka lat. Nie wskazano także, jaka jest procedura przekazania tych akt. Z faktu, że miejsce przechowywania archiwum kapituły jest Archiwum Archidiecezji Warmińskiej wynikają zadania, jakie stawiane są przez nadzór nad tymi materiałami archiwalnymi. Dyrektor ma obowiązek udzielić informacji o znajdujących się w aktach i dokumentach kapituły zdarzeniach, a w przypadku konieczności bezpośredniego wglądu w dokumenty sekretarz Kapituły ma uzgodnić czas ich udostępnienia (art. 24).

Kapituły Kolegiackiej przekazują materiały archiwalne do właściwego archiwum parafialnego, przy którym ma swoją siedzibę kapituła kolegiacka np. zgodnie ze Statutem Kapituły Kolegiackiej Świętego Wojciecha w Jaworznie, Archiwum Kapituły mieści się w siedzibie parafii kolegiackiej (art. 14).

\section{ZAKOŃCZENIE}

Przedstawione współczesne statuty kapituł katedralnych i kolegiackich zawierają przepisy dotyczące zasad funkcjonowania archiwów tych instytucji. Niestety stwierdzić należy, że mają one charakter bardzo ogólny i nie wskazują, jakie powinny obowiązywać procedury dotyczące przechowywania, porządkowania, zabezpieczania i udostępniania materiałów archiwalnych wytworzonych przez te instytucje. Wskazane zostały jedynie osoby, które mają troszczyć się o archiwum i w niektórych statutach miejsce przechowywania tych materiałów. Celowe jest bliższe określenie zasad funkcjonowania tego archiwum, zwłaszcza wówczas, gdy kapituła prowadzi nie tylko archiwum bieżące, lecz także archiwum historyczne. Konieczne byłoby określenie zasad i procedur jego prowadzenia. Wydaje się, że bardziej celowe, z uwagi na zachowanie zasad bezpieczeństwa, byłoby prze- 
kazywanie materiałów historycznych kapituły do przechowywania w archiwum historycznym diecezji.

\section{BIBLIOGRAFIA}

\section{ŹRÓDŁA PRAWA}

Codex Iuris Canonici Pii X Pontificis Maximi iussu digestus Benedicti Papae XV auctoritate promulgatus (27.05.1917), AAS 9 (1917), pars II, s. 1-593.

Sacrosanctum Concilium Oecumenicum Vaticanum II, Decretum de pastorali episcoporum munere in Ecclesia Christus Dominus (28.10.1965), AAS 58 (1966), s. 673-696; tekst polski: Sobór Watykański II, Konstytucje, dekrety, deklaracje, tekst polski, nowe thumaczenie, Pallottinum, Poznań 2002, s. 236-258.

Paulus PP. VI, Litterae Apostolicae Motu Proprio Datae. Ecclesiae Sanctae Normae ad quaedam exsequenda SS. Concilii Vaticani II Decreta statuuntur, AAS 58 (1966), s. 757-787.

Sacra Congregatio pro Clericis, Litterae Circulares ad Praesides Conferentiarum Episcopalium de Consiliis Presbyteralibus iuxta placita Congregationis Plenariae die 10 Octobris 1969 habitae, AAS 62 (1970), s. 459-465.

Acta Consilii pro Publicis Ecclesiae Negotiis, De promovendis ad Episcopatum in Ecclesia latina, AAS 64 (1972), s. 386-391.

Kongregacja ds. Biskupów, Directorium Ecclesiae imago de pastorali ministerio Episcoporum, [w:] Enchiridion Vaticanum, t. IV, Roma [b.w.] 1978.

Codex Iuris Canonici auctoritate Ioannis Pauli PP. II promulgatus (25.01.1983), AAS 75 (1983), pars II, s. 1-317; tekst polski: Kodeks Prawa Kanonicznego, przekład polski zatwierdzony przez Konferencję Episkopatu, Poznań: Pallotinum 1984.

I Synod Diecezji Drohiczyńskiej. Statuty. Dokumenty wykonawcze, Drohiczyn: Drohiczyńskie Wydawnictwo Diecezjalne 1997.

Aby byli jedno. Drugi Synod Diecezji Sandomierskiej. Dekrety i instrukcje, Sandomierz: Wydawnictwo Diecezjalne 1999.

I Synod Diecezji Ełckiej 1997-1999, Ełk: Kuria Biskupia Diecezji Ełckiej 1999.

III Synod Archidiecezji Łódzkiej (1996-1998), Łódź: Wydawnictwo Archidiecezjalne Łódzkie 1999.

Pierwszy Synod Diecezji Warszawsko-Praskiej, Warszawa: Wydawnictwo Diecezji Warszawsko-Praskiej 2000.

I Synod Archidiecezji Białostockiej, Białystok: Kuria Metropolitalna Białostocka 2000.

Synod Archidiecezji Przemyskiej 1995-2000. Statuty i aneksy, Przemyśl: Wydawnictwo Archidiecezji Przemyskiej 2000.

Statuty I Synodu Diecezji Pelplińskiej, Pelplin: Bernardinum 2001.

IV Synod Archidiecezji Warszawskiej, Warszawa: Wydawnictwo AW 2003.

Pierwszy Synod Diecezji Rzeszowskiej 2001-2004, Rzeszów: Poligrafia Wyższego Seminarium Duchownego 2004.

I Synod Diecezji Sosnowieckiej. Prawo Partykularne Kościoła Sosnowieckiego, Sosnowiec: Wydawnictwo Diecezjalne 2005.

Dokumenty soborów powszechnych. Tekst grecki, łaciński, polski, r. II, oprac. A. Baron H. Pietras, Kraków: Wydawnictwo WAM 2007. 
Synod Archidiecezji Poznańskiej 2004-2008. Zwołany i przeprowadzony przez Arcybiskupa Stanisława Gądeckiego, t. I: Dokumenty, Poznań: Wydawnictwo Świętego Wojciecha 2008.

Pierwszy Synod Diecezji Toruńskiej. Prawo partykularne Kościoła Toruńskiego, Toruń: Toruńskie Wydawnictwo Diecezjalne 2011.

I (XIV) Synod Archidiecezji Warmińskiej (2006-2012). Misja Kościoła Warmińskiego w dziele Nowej Ewangelizacji, Olsztyn: Wydział Duszpasterski Kurii Archidiecezji Warmińskiej 2012.

Gdzie jest Bóg tam jest przyszłość. XLIII Synod Diecezji Płockiej. Prawo partykularne i program odnowy pastoralnej Kościoła Płockiego, Płock: Płocki Instytut Wydawniczy 2015.

\section{LITERATURA}

Abraham Władysław: Organizacja Kościoła w Polsce do połowy XII w., Lwów [b.w.] 1893.

Bilska-Ciećwierz Magdalena: Powstanie i organizacja kapituł kolegiackich metropolii gnieźnieńskiej w średniowieczu, Kraków: Societas Vistulana 2007.

Bochniak Władysław: Kapituła katedralna w Legnicy, Legnica: Parafia Katedralna p.w. św. Piotra i Pawła 2000.

Borucki Janusz: Kapituła katedralna i Rada Kapłańska - stary i nowy senat biskupa diecezjalnego, Studia Wtoctawskie 9 (2006), s. 244-257.

Chomiak Stanisław: Świdnicka Kapituła Katedralna, Świdnica: Świdnicka Kuria Biskupia 2009.

Czyżak Marta: Kapituła katedralna w Gnieźnie w świetle metryki z lat 1408-1448, Poznań: UAM. WT. Redakcja Wydawnictw 2003.

Dembiński Paweł: Poznańska kapituła katedralna schyłku wieków średnich. Studium prozopograficzne, Poznań: Wydawnictwo Poznańskiego Towarzystwa Przyjaciół Nauk 2012.

Dola Kazimierz: Wrocławska kapituła katedralna w XV w., Nysa [b.w.] 1977.

Dyduch Jan: Kapituła Katedralna i Rada Kapłańska, Prawo Kanoniczne 25 (1982), nr 3-4, s. 79-99.

Gerlic Henryk: Kapituła głogowska w dobie piastowskiej i jagiellońskiej (1120-1526) Gliwice: Wydawnictwo NOTA 1993.

Góralski Wojciech: Kapituła katedralna w Płocku XII-XVI w. Studium z dziejów organizacji prawnej kapituł polskich, Płock: Płockie Wydawnictwo Diecezjalne 1979.

Grad Stanisław, Różański Mieczysław: Kapituła Katedralna Łódzka, Łódź: Archidiecezjalne Wydawnictwo Łódzkie 2007.

Kopiczko Andrzej: Dzieje Warmińskiej Kapituły Katedralnej, t. II: od 1821 roku, Olsztyn: Instytut Historii i Stosunków Międzynarodowych UWM 2010.

Korytkowski Jan: Prałaci i kanonicy katedry metropolitalnej gnieźnieńskiej od roku 1000 do dni naszych, t. 1-4, Gniezno [b.w.] 1883.

Królik Ludwik: Kapituła kolegiacka w Warszawie do końca XVIII wieku, Warszawa: Wydawnictwo Archidiecezji Warszawskiej 1990.

Librowski Stanisław: Kapituła katedralna włocławska - zarys dziejów i organizacji, Włocławek 1948.

Marchal Guy P.: Domkapitel, w: Theologische Realenzyklopädie, t. IX, Berlin-New York: De Gruyter 1982, s. 136-140.

Nitzschke K.: Domkapitel, w: Evangekisches Kirchenlexikon, t. I, Gottingen: V \& R 1956.

Radzimiński Andrzej: Duchowieństwo kapitulne w Polsce średniowiecznej i wczesnonowożytnej - pochodzenie i funkcjonowanie elity kościelnej, Toruń: Wydawnictwo Uniwersytetu Mikołaja Kopernika 2000.

Rittner Edward: Prawo kościelne katolickie, t. I , Kraków [b.w] 1899. 
Silnicki Tadeusz: Dzieje i ustrój Kościoła Katolickiego na Śląsku do końca w. XIV, Warszawa: Wydawnictwo PAX 1953.

Szymański Józef: Kapituła kolegiacka w Wojniczu (1465-1786), Lublin: Towarzystwo Naukowe KUL 1962.

Warmińska Kapituła Katedralna. Dzieje i wybitni przedstawiciele, red. A. Kopiczko, J. Jezierski, Z. Żywica, Olsztyn: : Instytut Historii i Stosunków Międzynarodowych UWM 2010.

Wętkowski Krzysztof: Kapituła katedralna w świetle postanowień Soboru Watykańskiego II i norm Kodeksu prawa kanonicznego z 1983 roku, Prawo i Kościót 2 (2000), s. 71-82.

Wroceński Józef: Rola i zadania prezbiterium w życiu Kościoła partykularnego, Warszawa: Wydawnictwo ATK 1998.

Wyczawski Hieronim E.: Przygotowanie do studiów w archiwach kościelnych, red. T. Moskal,

A. K. Sitnik, Kalwaria Zebrzydowska: Wydawnictwo OO. Bernardynów „Calvarianum” 2013.

X A.S., Kapituła, w: Encyklopedia Kościelna, t. IX, Warszawa [b.w.] 1876, s. 519-520.

Zachorowski Stanisław: Rozwój i ustrój kapituł polskich w wiekach średnich, Kraków [b.w.] 1912.

\title{
ARCHIWUM KAPITUŁY KATEDRALNEJ I KOLEGIACKIEJ
}

\author{
Streszczenie
}

Kapituły katedralne i kolegiackie należą do jednych z najstarszych instytucji działających w strukturach diecezji. W ciągu wieków zwłaszcza kapituły katedralne brały udział w sprawowaniu władzy biskupa diecezjalnego. W toku ich działania powstawały materiały, które później były przechowywane w archiwum kapitulnym. Obecne statuty kapituł wskazują, że każda z nich powinna prowadzić archiwum. Zajmować się ma nim oddelegowany kanonik, który ma wpisane w zakresie obowiązków zadania związane z jego kierowaniem. Jest to archiwum bieżące. Potem dokumentacja kapituły przekazywana jest do archiwum bieżącego kurii diecezjalnej lub do archiwum historycznego.

Słowa kluczowe: kapituła katedralna; kapituła kolegiacka; archiwum; synod

\section{ARCHIVES OF THE CATHEDRAL AND COLLEGIATE}

\section{Sum mary}

Cathedral and collegiate chapters belong to the oldest institutions in diocesan structures. Over the centuries, especially the cathedral chapters took part in exercising the powers of the ordinary. In the course of their activities, materials were created, and later stored in the chapter archives. The current chapter statutes indicate that each of them should keep an archive. A delegated canon is to take care of it. This is the current archive. Then the chapter's documentation is transferred to the diocesan current archive or to the historical one.

Key words: cathedral chapter; collegiate chapter; archives; synod 